\title{
РОЗРОБКА ЦУКЕРОК МАРЦИПАН НА ОСНОВІ АРАХІСОВОЇ ПАСТИ ТА ПАСТИ 3 ЦИКОРІЮ
}

\author{
Н.П. ШАПОВАЛОВА, Т.Н. АРТЮХ \\ Национальный университет пищевых технологий
}

\section{РАЗРАБОТКА КОНФЕТ МАРЦИПАН НА ОСНОВЕ АРАХИСОВОЙ ПАСТЫ И ПАСТЫ ИЗ ЦИКОРИЯ}

\author{
N.P. SHAPOVALOVA, T.N. ARTYUKH \\ National University of Food Technology
}

\section{THE DEVELOPMENT OF MARZIPAN BASED ON PEANUT PASTE AND PASTE OF CHICORY}

\section{https://doi.org/10.36910/6775-2310-5283-2018-11-05}

Мета. Розробка иукерок мариипан з заміною головного компонента горіха мигдалю на арахісову пасту та використання пастоподібного екстракту ичикорію з метою розширення асортименту кондитерських виробів збагачених біологічно активними компонентами та надання їм нових смакоароматичних властивостей.

Методика. При дослідженнях використовували передбачені діючими держсавними стандартами методи органолептичного оцінювання, сенсорна характеристика, метод профілю флейвору, дескриптори, профілограмму, які дозволяють встановити якісні характеристики розроблених иукерок мариипан, зокрема органолептичні властивості.

Результати. Наведено результати сенсорного аналізу розроблених иукерок марциипан на основі арахісової пасти, з частковою заміною иукрового сиропу пастоподібним екстрактом ичикорію. Показано доиільність його використання для виявлення дескрипторів органолептичних властивостей иукерок. Запропоновано використання кавової оболонки та шоколадної глазурі.

Наукова новизна. Розроблено технологію виготовлення иукерок мариипан на основі арахісовій пасти. Встановлено, що використання пастоподібного екстракту ичикорію дозволить не тільки знизити енергетичне навантаження готових иукерок але й надасть їм фізіологічно-функиіональних властивостей.

Практична значимість. Доведено доиільність використання кавової оболонки та шоколадної глазурі з метою надання смакоароматичних властивостей. Проведено органолептичне оцінювання иукерок маричипан на основі методом профілю флейвору.

Ключові слова: иукерки марциипан, арахіс, ядра, арахісова паста, екстракт цикорію, метод профілю флейвору, профілограма. 


\section{Постановка проблеми у загальному вигляді та іï зв'язок із} важливими науковими чи практичними завданнями. Цукрові кондитерські вироби, зокрема цукеркові вироби з масами, що містять горіхи, відносяться до найбільш високоякісних. Вони відрізняються значною харчовою цінністю завдяки високому вмісту жирів, білків, вуглеводів та наявності таких ессенціальних речовин як вітаміни, цінні мінеральні речовини та ін. Цукерки марципан виготовляють із марципанових мас, які в свою чергу поділяють на дві групи: сирий марципан і заварний марципан. Перший готують перемішуванням тертого сирого мигдалю або інших горіхів 3 цукровою пудрою. Зазвичай додається невелика кількість патоки (близько 6\% до маси готового виробу). Заварний марципан отримують, змішуючи терті горіхи з гарячим цукрово-патоковим сиропом. Проста марципанова маса, внаслідок порівняно високій вологості і низького вмісту цукру (близько 60\%), може при несприятливих умовах бути середовищем для розвитку мікроорганізмів. Тому вона схильна до небезпеки бродіння та пліснявіння. Для запобігання псування марципану горіхи піддають легкому обсмажуванню або сушінню.

Заварний марципан більш стійкий при зберіганні. 3 мас заварного марципану виготовляють корпуси цукерок, які потім глазурують шоколадом.

Марципанова маса відрізняється від інших горіхових мас, зокрема праліне, по-перше, тим, що основною сировиною є тільки ядра горіхів; подруге, горіхи перед використанням не обсмажуються; по-третє, масова частка сухих речовин марципанової маси значно нижча (близько 90 \%).

Для виготовлення марципанових мас за оригінальним рецептом використовують ядро свіжомеленого мигдалю. Дивлячись на порівняно високу ціну мигдалю на сьогодні все частіше використовують арахіс у виробництві марципану. Виходячи 3 цього основним завданням нашої розробки було заміна горіхів мигдалю $\mathrm{i}$ в якості альтернативи використовувати арахісову пасту, як основний компонент приготування цих цукерок. Це дозволить знизити собівартість, i таким чином цей продукт буде більш доступним, до того ж ядра арахісу користуються непоганою популярністю.

Так як смакові якості арахісового марципану нижче, ніж мигдального, нами запропоновано урізноманітнити їх смак за допомогою часткової заміни цукрового сиропу у рецептурі на пастоподібний згущений екстракт цикорію.

Окрім надання функціональних властивостей розробленим цукеркам завдяки інуліну, використання екстракту цикорію надасть можливість знизити 
Товарознавчий вісник. - 2018. - Випуск 11.

солодкість цукровмістного продукту та надати антиоксидантних властивостей.

Аналіз останніх досліджень, у яких започатковано вирішення проблеми. Якість цукерок оцінюють відповідно до діючих стандартів України (ДСТУ 4135-2002, 4228:2003, 4326:2004, 4688:2006, 5060:2008) за зовнішнім виглядом, формою, запахом і смаком, вологістю, масовою часткою розчинних вуглеводів, жиру, редукуючих речовин, вмістом токсичних елементів, мікотоксинів і пестицидів, мікробіологічними показниками.

Показники що визначають безпечність споживання цукерок - це вміст солей важких металів, афлатоксинів, продуцентів мікробіологічних перетворень складових частин виробів, мутагенних сполук, які утворюються при порушенні технологічних режимів обробки сировини, режимів та умов зберігання.

Цукерки можуть мати ряд дефектів: рубці на дні виробів, пухирці повітря у глазурі (виникають внаслідок великої швидкості перемішування або у разі використання холодної глазурі). При надмірному темперуванні одержують грубу структуру глазурі. Цукрове посивіння може з'являтись при високій вологості навколишнього середовища, переохолодженні, стиканні 3 вологими предметами. Деформовані вироби, неповне покриття (виникає при низькій температурі глазурі, недостатньо ефективному іiі перемішуванні), розм'якшення глазурі, маслянистість, тьмяний глянець (виникає у випадку обмеженого використання глазурі, підданої темперуванню, при підвищеній вологості навколишнього середовища, неправильному охолодженні).

Розробці рецептур цукерок, які б характеризувалися високими органолептичними властивостями, збагачених фізіологічно-функціональними компонентами 3 метою розширення асортименту кондитерських виробів покрашеного складу присвячені роботи видатних вчених Іоргачова К.Г. [5], Дорохович А.М. [6], Рудавська Г.Б. [7], Гавва О.О. [8] та ін.

Не дивлячись на велику кількість розробок та впроваджень у виробництво є постійна потреба вітчизняних виробників конкурувати як на внутрішньому так i на європейському ринках та відповідати вимогам міжнародних стандартів.

Тому, метою даного дослідження $\epsilon$ розробка цукерок марципан 3 заміною головного компонента горіха мигдалю на арахісову пасту та використання пастоподібного екстракту цикорію.

Об'єктом дослідження слугували цукерки марципан виготовлені за класичною рецептурою на основі арахісовою пасти від TM "Good Energy" 
Україна, м. Дрогобич, Львівська область, та з частковою заміною цукрового сиропу (15\%) пастоподібним екстрактом кореня цикорію звичайного [11].

Виклад основного матеріалу дослідження з повним обгрунтуванням отриманих наукових результатів. Представлені в цьому огляді дані показують, що використання арахісу для харчових цілей пояснюється не тільки привабливими смаковими якостями, але і наявністю природного комплексу основних поживних речовин: білків, жирів i вуглеводів, амінокислот, ненасичених жирних кислот, а також мінеральних речовин i вітамінів А, В1, В2, РР, С. Присутні в ньому і антиоксиданти - речовини, що захищають клітини організму від несприятливого впливу вільних радикалів. Саме це робить арахіс одним 3 найефективніших засобів у профілактиці серцево-судинних захворювань. Відповідно до недавніх досліджень, регулярне вживання арахісової пасти (в розумних межах) на 15-20\% знижує ризик серцево-судинних захворювань.

Ядра арахісу багаті рослинним жиром і перетравлюється білком. Вміст жиру досягає 40-60\% i його засвоюваність дуже висока. Коефіцієнт засвоюваності жиру арахісу становить 95,5\%. Завдяки цьому арахіс відносять до висококалорійних продуктів [1].

На відміну від дорогих горіхів, таких як кеш'ю, фісташки, мигдаль i волоський горіх, арахіс коштує недорого, а його переваги для нашого організму аналогічні. Ця поживна, але калорійна їжа може бути здоровим доповненням практично до будь-якої дієти, якщо вживати іiі в помірній кількості.

В останні час набирають популярність продукти на основі ядер арахісу. Продуктом, виготовленим з висушеного і обсмаженого арахісу, є арахісова паста. Вона зручна у використанні, швидка в застосуванні, цей продукт зберігає відчуття ситості довше за рахунок великого вмісту білка.

Арахісова паста має неповторний запахом обсмаженого арахісу, має приємну кремоподібну текстуру. Колір може бути і світло-коричневим, i темно-карамельним, все залежить від ступеня обсмаження i способу приготування [2].

Крім своїх чудових смакових якостей, арахісова паста містить життєво важливі поживні речовини, які необхідні організму.

Вироби на основі арахісової пасти містять достатню кількість клітковини, щоб допомогти доповнити споживання цієї поживної речовини 3 інших продуктів. Клітковина допомагає регулювати роботу травної системи, сприяючи здорової дефекації, i, як і білок, клітковина, довше зберігає почуття 
ситості між прийомами їжі. Волокна також допомагають в боротьбі 3 хворобами серця, цукровим діабетом і ожирінням [3].

Цикорій звичайний (Cichorium intybus L.) відомий людям із давніх давен як рослина, всі частини якої (корені, стебла, листя) використовуються як засоби народної медицини та харчові продукти. Багатий хімічний склад надає цикорію переваги перед іншими інуліноносіями. Основним біологічно активним компонентом цикорію $є$ інулін (до 35 \%), який відноситься до класу фруктанів, має високу біологічну активність і специфічну дію на організм людини. Інулін гігроскопічний, легкорозчинний в гарячій воді й важко - в холодній [7]. Доведено гіпоглікемічну та гіпохолестеричну дію інуліну. Він не засвоюється у верхніх відділах шлунково-кишкового тракту, а сприяє нормалізації травної системи, поліпшенню метаболізму, виступаючи пребіотиком. Сучасні дослідження вказують, що інулін має імуномоделюючі та антистресові властивості [10]. Саме завдяки поєднанню відмінних органолептичних властивостей i комплексу цінних біологічно активних сполук цикорій став перспективною сировиною для виробництва різноманітних харчових продуктів, зокрема кондитерських виробів та напоїв.

Зіставивши всі корисні властивості арахісової пасти і переваги цикорію для нашого організму в іiі споживанні, в даній роботі була розроблена технологія виготовлення цукерок марципан на основі продуктів які мають фізіологічно-функціональний ефект [9].

У даній роботі взяли за основу класичний рецепт приготування заварного марципану (на основі арахісової пасти), частково замінюючи в рецептурі цукровий сиром цикорієм для зниження енергетичного навантаження та поліпшення смаку. Це дає нам абсолютно відмінні на смак, запах і склад суміші для різних смакових переваг людей.

Розроблені цукерки оцінювали шляхом сенсорного аналізу органолептичних показників з використанням методу визначення профілю флейвору. Метод профілю флейвору $\epsilon$ одним із групи методів, використовуваних для опису сенсорних характеристик i вважається основоположним для багатьох інших описових методів. Сьогодні під поняттям флейвору розуміють комбінований ефект від смакових властивостей, ароматичного сприйняття та відчуттів дотику в порожнині рота [12].

Метод профілю флейвору - це спроба охарактеризувати "флейвор", беручи до уваги всі дескриптори, які формують загальне враження від продукту. По суті, метод профілю флейвору описує загальне враження від 
продукту з точки зору п’яти основних критеріїв: характеру дескрипторів, їх інтенсивності, порядку прояву цих дескрипторів, післясмаку та їх повноти (феномен, який виражається загальним враженням від поєднання складових продукту) [13].

Основою для складання нових композицій $є$ арахісовий марципан (за класичною рецептурою). В якості натуральних добавок до нього використані: пастоподібний цикорій, кавова оболонка (композиція 1) та шоколадна глазур (композиція 2), які внесли унікальні смакові відтінки, гармонійно доповнили характерний смак і аромат. Результати візуально представлені у вигляді профілю флейвору (рис. 1).

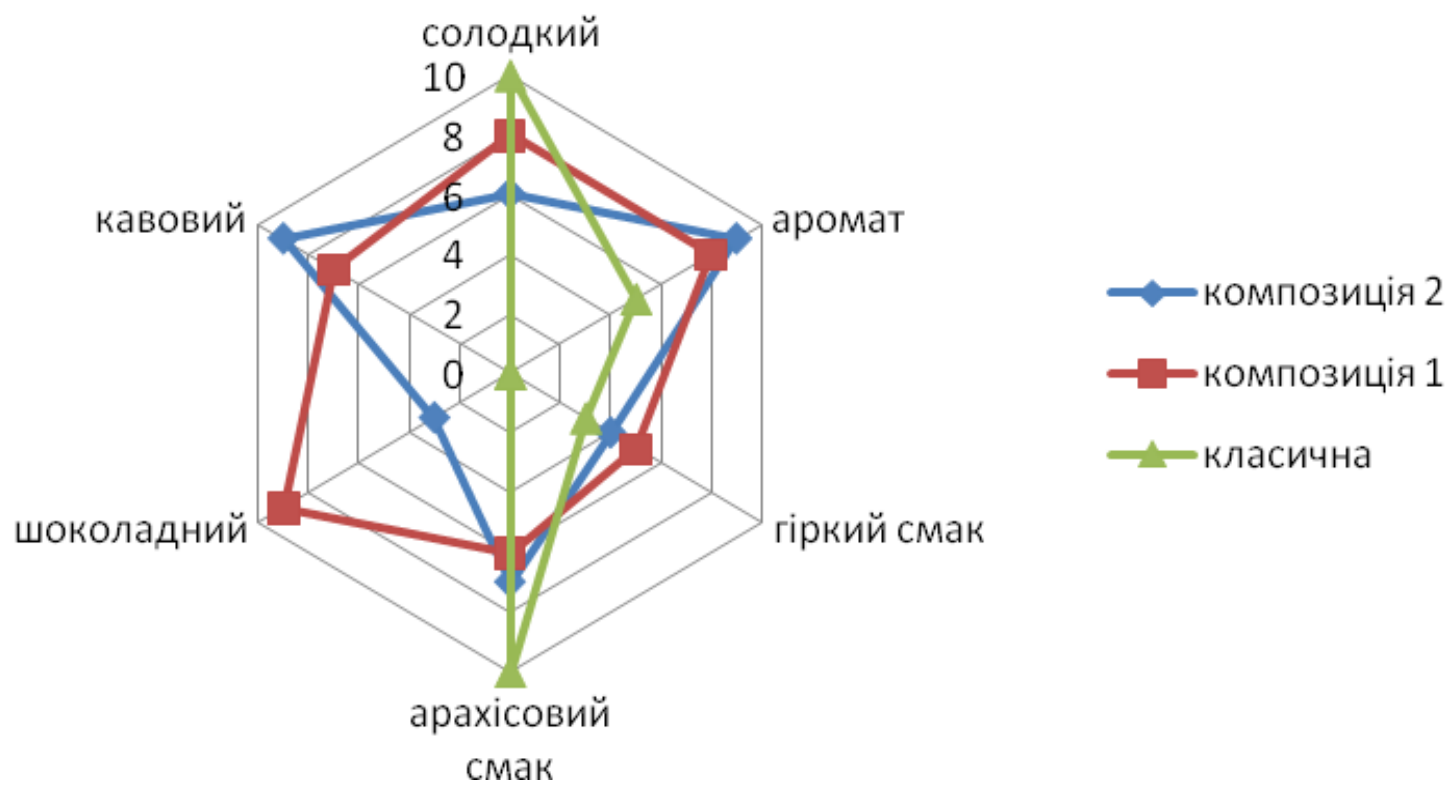

\section{Рис. 1. Смакоароматичний профіль арахісовий марципан / кавова оболонка / шоколадна глазур}

Органолептичний аналіз показав, що використання цикорію дозволяє знизити солодкість виробу та надати йому приємного смаку та аромату кави. Окрім того є доцільно використовувати в якості глазурі 4\% кавової оболонки та 50\% шоколадної маси 3 метою поліпшення смакоароматичних характеристик арахісового марципану.

Висновки та перспективи подалыших досліджень. Досліджуючи флейвор композицій, тобто комплексне відчуття смаку, аромату і присмаку, необхідно відзначити, що продукт за критеріями повноти і гармонійності смаку, виразності аромату після додавання інгредієнтів перевершує класичний марципан в 2 рази. Згідно з проведеним дослідженням споживчих переваг, 
арахісовий марципан з використанням натуральних біологічно цінних добавок має отримати популярність, так як пропонує нові смаки звичного продукту, а саме приємний кавовий смак та аромат.

В цілому, отримані композиції визнані якісними та збалансованими за органолептичними показниками. Визначені дескриптори смаковитості рекомендується використовувати для удосконалення рецептур із метою підвищення якості напоїв і задоволення вимог споживачів. За рахунок внесених рецептурних компонентів цукерки збагачені високим вмістом поживних речовин, вітамінами і мінеральними речовини, що буде доведено у наших подальших дослідженнях.

\section{Література}

1. Шепелев В. П. Целебные свойства орехов / В. П. Шепелев. - Ростов н/Д : Феникс, 2002. - 128 с.

2. [Електронний pecypc]: https://ora-eko.com.ua/p358815964-arahsova-pastaarahsove.html

3. [Електронний pecypc]: https://ora-eko.com.ua/p358815964-arahsova-pastaarahsove.html

4. ДСТУ 4135-2002 . Цукерки. Загальні технічні умови.

5. Іоргачева К.Г. Научные основы технологий кондитерских изделий с использованием функциональных растительных добавок: Дис... д-ра техн. наук. - Одесса, 2004. $-590 \mathrm{c}$.

6. Дорохович А.М. Методологічний підхід до розроблення раціональних технологій комбінованих кондитерських виробів, що формуються методом ко-екструзії. / А.М. Дорохович, В.І. Оболкіна // Вісник ДонДУЕТ. - 2007. - №1(33). - С. 132 - 137.

7. Рудавська Г.Б. Мінеральний склад нових пастильних виробів оздоровчого спрямування / Г.Б. Рудавська, Н.П. Шаповалова // Товарознавчий вісник - ЛНТУ. - 2012. C. $347-352$.

8. Гавва О.О. Удосконалення технологій неглазурованих цукерок 3 метою подовження терміну їх зберігання: Дис...канд. техн. наук. - К.: НУХТ, 2006.

9. Матвеева Т.М. Физиологически функциональные пищевые ингредиенты для хлебобулочных и кондитерских изделий: монография / Т. В. Матвеева, С. Я. Корячкина. Орел. : ФГБОУ ВПО Госуниверситет-УНПК, 2012. - 947 с.

10. Рудавська Г. Б. Проблеми якості та безпечності розчинних напоїв на основі цикорію / Г. Б. Рудавська, І. В. Хахалєва : матеріали міжнар. міждисциплінарної наук.практ. конф. ["Сучасні аспекти збереження здоров'я людини"], (с. Солочин, Свалявський рн, 17-18 квіт. 2015 р.).—К. : Центр учбової літ-ри, 2015. — С. 109—113.

11. Авторское свидетельство (21) 4861520/13 (22) 05.06 .90 (46) 07;04.92. Бюл. № 13 (71) Киевский технологический институт пищевой промышленности (72) Ю.В. Булий, В.Н. Швец, П.С. Цыганков, Г.3. Валлис, Н.З. Калниньш и М.С.Лавкай (53) 663.95(088.8) (56) 
Авторское свидетельство СССР http://www.findpatent.ru/patent/172/1724156.html FindPatent.ru - патентный поиск, 2012-2018.

12. Caul J. F. The profile method of flavor analysis / J. F. Caul ; ed. E. M. Mrak, G. F. Stewart // Advances in Food Research. - 1957. — Vol. 7 (1). — 40 p.

13. ДСТУ ISO 6564:2005 (ISO 6564:1985, IDT). Дослідження сенсорне. Методологія. Методи створення спектра флейвору. - [Чинний від 2005-05-25]. — К. : Держспоживстандарт України, 2006. - 9 с.

Цель. Разработка конфет маричипан с заменой главного компонента ореха миндаля на арахисовую пасту и использования пастообразного экстракта иикория с иелью расширения ассортимента кондитерских изделий обогащенных биологически активными компонентами и предоставления им новых вкусоароматических свойств.

Методика. В исследованиях использовали предусмотренные действующими государственными стандартами методы органолептического оценивания, сенсорная характеристика, метод профиля флейвору, дескрипторы, профилограмму, которые позволяют установить качественные характеристики разработанных конфет мариипан, в частности органолептические свойства.

Результаты. Приведены результаты сенсорного анализа разработанных конфет мариипан на основе арахисовой nасты, с частичной заменой сахарного сиропа пастообразным экстрактом ичикория. Показана цчелесообразность его использования для выявления дескрипторов органолептических свойств конфет. Предложено использование кофейной оболочки и шоколадной глазури.

Научная новизна. Разработана технология изготовления конфет марципан на основе арахисовой nacmbl. Установлено, что использование пастообразного экстракта изикория позволит не только снизить энергетическую нагрузку готовых конфет, но и предоставит им физиологически функииональные свойства.

Практическая значимость. Доказана иелесообразность использования кофейной оболочки и шоколадной глазури с иелью предоставления вкусоароматических свойств. Проведено органолептическая оченка конфет мариипан на основе арахисовой пасть методом профиля флейвору.

Ключевые слова: конфеты мариипан, арахис, ядра, арахисовая паста, экстракт цикория, метод профиля флейвору, профилограмме.

Purpose. Development of marzipan with the replacement of main component of almond nut by paste of peanut and use paste of chicory with the aim of expanding the range of confectionery products, enriched with biologically active components and providing new flavor properties.

Methodology. The study used methods according to the requirements of state standards methods of organoleptic evaluation, sensory characteristics, profile of flavor, descriptors, profilogram.

Findings. The results of a sensory analysis of the developed marzipan candy from peanut paste and the replacement of a sugar syrup paste chicory. is presented The expediency of a 
sensory analysis use for revealing descriptors of organoleptic properties of candy. The use of coffee shell and chocolate glaze is suggested.

Originality. Developed technology of manufacturing marzipan with peanut paste. Providing that the use of a paste of chicory will help reduce the energy load and enhancing their physiological functional value.

The practical value. The expediency of using the coffee shell and chocolate glaze is proved with the purpose of providing new flavor properties. Was carried out organoleptic assessment of marzipan based on peanut paste using the flavor profile method.

Key words. marzipan, peanuts, kernels, peanuts paste, flavor properties $\_$chicory extract, descriptors, profilogram.

Рекомендовано до публікації докт. техн. наук, професором, Лущьького НТУ Байдаковою Л.І. Стаття надійшла в редакијю 07.03.2018 р. 